\title{
A COMPARISON OF THE SPEECH STYLES OF NIGERIAN AND CHINESE EFL LEARNERS IN MALAYSIA
}

\author{
Pauline Mackenzie \\ Centre for English Language Studies, Faculty of Arts, Sunway University, Selangor \\ E-mail: mackenzie412@gmail.com
}

Kuang Ching Hei

Department of English Language, Faculty of Languages and Linguistics, University of Malaya, Kuala Lumpur E-mail: kuangch@um.edu.my

APA Citation: Mackenzie, P. \& Hei, K. C. (2015). A comparison of the speech styles of Nigerian and Chinese EFL learners in Malaysia. Indonesian EFL Journal, 1(2), 173-188

\begin{abstract}
This paper focused on the speech styles of two groups of learners, Nigerian learners with English as their official language and Chinese learners with English as a foreign language studying in Malaysia. A questionnaire was developed to extract personal details while a classroom task was given to gather data. Consent was given voluntarily. Spoken data were recorded, transcribed verbatim and then analyzed and findings were further substantiated by an interview. Analysis showed that Nigerian learners are less prone to using fillers as compared to Chinese EFL learners. This implied that Chinese EFL learners were less comfortable in using English. Both Nigerian and Chinese learners used the same amount of intensifiers suggesting that they do not feel passionate when talking about themselves, as the task demanded. The findings of this study will enable foreign language learners to understand themselves better and assist local teachers and classmates to be more tolerant when communicating with them as it can help to minimize misunderstandings. Nonetheless, further research may be required to verify the findings.
\end{abstract}

Key words: Speech styles, fillers, intensifiers, Nigerian, Chinese, EFL learners

\section{INTRODUCTION}

As globalization takes place, it is inevitable for internationalization to co-occur where students from one country pursue further education in another. It is also good to recruit foreign learners as their presence can broaden the significance of education as well as introduce new cultures and knowledge which can enhance further mutual understanding of each other.

With the influx of more foreign students, it is imperative that locals, particularly those in the education line, be given more information about the new residents coming to reside in the country so that miscommunication and misunderstandings can be mitigated before they explode to involve violence.

Observations show that Malaysia has many Chinese and Nigerian students studying in local institutions of higher learning and some experiences with Nigerians suggest that they have a peculiar way of communicating even though they are competent in the English language. In contrast, it was also observed that Chinese students from mainland China seem to be struggling with using the English language especially when interacting among locals. It appears that some locals find it uneasy interacting with these two groups of students, hence there is a need to conduct an exploratory study in order to extract some evidence which can be used to support the observations. Specifically, there is a need to study how these two groups of students differ in the way they communicate their meanings and to what extent can their differences be bridged.

The selection of these two nationalities was made based on the misunderstandings (e.g. providing answers not related to questions asked) or miscommunications (e.g. giving wrong information to friends) which had occurred within the class in which the researcher was conducting as their English language lecturer. 
It was also noted that students of these two nationalities rarely communicate with each other as they could not understand each other. This study is restricted to looking at two selected linguistic features only, based on Lakoff's $(1973 ; 1975)$ work.

This study aims to identify the speech style differences of learners from two nationalities: Nigerian and Chinese EFL learners. Specifically, it aims to explore the linguistic differences in their spoken utterances in terms of: 1) fillers and 2) intensifiers.

Every individual has their own peculiar manner of speaking and among cultural groups; some differences are more announced than others. In the Malaysian context, it is noted that Malay speakers tend to be indirect (see Asmah Haji Omar, 1992, 1995; Jamaliah Mohd Ali, 1995, 2000) whereas Chinese speakers tend to be direct (see David \& Kuang, 1999; Kuang, 2002). Other studies have also noted some gender differences in oral interactions. Tannen (1990) notes that men and women speak in differently because of the way they are brought up. Tannen (ibid.) adds that "we need to identify and understand these differences to avoid misunderstandings" (p.17). Like Tannen (1990), Reiman (2006) believes that communication gaps occur due to the different communication styles among humans. Reiman (2006) mentions that problems in communication happen when the intended message is not conveyed properly or when the speakers have been misunderstanding.

Focusing on cultural differences Ahmad Al-Issa (2003) says that when people from different cultures interact, they often bring culturally inherited sets of constraints to monitor and evaluate their own speech as well as the speech of others. These sets of constraints consist of values, preferred communication styles, expectations and interpretations which affects communication. For example, when two people from different backgrounds talk to each other, certain things such as their opinion on a certain issue can cause them to feel uneasy with each other if they do not have the same opinion on the said issue. Since language cannot be separated from the culture of the person, second language (L2) learners who are speaking in a target language (L2) may have been influenced by their native language (L1) background. Consequently, they may discover that using L2 can become a great challenge (Bardovi-Harlig \& Hartford, 1990; Eisenstein \& Badman, 1986; Olshtain \& Cohen, 1983) as their messages may likely be misinterpreted, and their speaking styles or behavior may also influence what others think of them. All these information suggest that communication can be affected by many factors including situation, culture, gender and many others.

Coupland (2007) suggests that style is a way of doing something and speech styles consist of items such as phonological, morphological, syntactical and lexical items. According to his framework (2007), styles carry social meanings when they are used. Often, they are used as strategy to show social differences which enables speakers to construct identity of the speakers so that they become accepted by the target community. For example, in schools, students may talk like their friends in order to be accepted by the group of friends. The reason for English language learners to accommodate depends on the degree to which they want to be accepted into the society of the said country. Wide (2010) says that, if an individual moves to a new place where the surrounding is unfamiliar, he or she would likely have a high need for social approval; thus, speaking style would be important.

Giles (1973) says that people tend to change their speech characteristics (accent, pauses, speech rate) during interactions to achieve certain goals. Speech shift are changes made by a person when speaking that can have different circumstances depending on the context of interaction (Giles, Mulac, Bradac \& Johnson, 1987). He also says that there are factors which influences speech choices and it includes the place where the conversation occurs, (classroom as opposed to canteen), the topic of the conversation itself (academic as opposed to shopping) and also the kind of interlocutors (teacher vs. student as opposed to friend vs. friend) (Giles \& Smith, 1979). 
Speech styles can also be evaluated through pauses and language intensity (Giles \& Street, 1985). Street \& Hopper (1982) says that the extent to which the quality of the speaker's language toward a subject which deviates from neutrality is language intensity. Street \& Giles (1982) continue to say that, when a person becomes more emotional about the subject he/she is talking about, the language used becomes more intense. For example, when a speaker is talking about a topic which they really like, they tend to speak more passionately and aggressively about the topic compared to a topic which they dislike. Therefore, the language used will be more intense and emotional compared to when talking about a topic which they do not fancy. They also mentioned that people tend to converge more on vocal intensity when they are aware that they have similar attitudes (Street \& Giles, 1982). These similarities then tend to draw speakers together and indirectly, it promotes harmony and tolerance with one another.

Erickson, Lind, Johnson and O'Barr (1978) argue that speech style is linked to social power and status. They say that lowstatus people generally use powerless speech style with the use of intensifiers, hedges, hesitations, hypercorrect grammar, questioning forms, polite forms and gestures. However, (Bradac \& Mulac, 1984; Hosman, 1989; Hosman \& Siltanen, 1994) suggest that intensifiers may not be perceived as powerless and may even have powerful connotations in certain contexts as they may indicate certainty or control (Hosman \& Siltanen, 1994; McMullen \& Pasloski, 1992). Bradac, Mulac \& Thompson (1995) says that when components of powerful and powerless speech styles are examined, intensifiers were found to have occurred more frequently than hedges or hesitations, with intensifiers being used more by women and hedges by men. Therefore hedges and intensifiers should not be regarded as "powerless language". According to Smith, Siltanen \& Hosman (1998), a powerless style is characterized by the presence of language features such as hedges ('sort of', 'kind of'), hesitations ('um, er'), intensifiers ('surely', 'certainly'), polite forms ('yes sir', 'please'), tag questions ('pass me that, won't you'), and deictic phrases (ones indicating location or direction, such as 'over there') whereas a high power style does not have any of these features. They continue to say that the use of hedges may suggest that the speaker is uncertain about the position they are advocating which causes the listener to scrutinize message arguments more carefully (Smith, Siltanen \& Hosman, 1998). Therefore, messages that are presented in an uncertain way may affect the message processing differently than an argument with the same strength but presented in a speaker certainty way (Smith, Siltanen \& Hosman, 1998). A speaker using powerless speech style indicates a lack of confidence or certainty (Parton, Siltanen, Hosman \& Langenderfer, 2002). Erickson, Lind, Johnson \& O'Barr (1978) said that powerless speech may be too costly for listeners as it makes them work harder to understand what the speaker is saying.

Stylistics, according to Crystal (1971), refers to the linguistic study of systematic, situationally-distinctive, intra-language variation. By 'situation' he refers to the subset of non-linguistic variables which a native speaker can intuitively identify as linguistics features in an utterance. 'Feature' however, refers to any amount of speech or writing which may be singled out from language and discussed (word, morpheme, sentence, structural relationship and others). They include features such as hesitations, tag questions, hedges, disclaimers, intensifiers and formal addresses. Stylistic features influence how a speaker is evaluated both positively and negatively when speaking (Fragale, 2006).

Fillers are words or sounds that fill up a gap in an utterance (Cappelli, 2008). In English, the most common filler sounds are $e r, u h$ and $u m$. Fillers can also occur at different positions in a sentence.

When a speaker takes a longer time to produce an utterance, he/she might lose the listener's attention but if he/she rushes to produce an utterance that is defective, he/she risks being misunderstood (Clark \& Brennan, 1991). So, the speaker may signal the delay of producing a word or phrase by using a filler 
such as um, er and uh (Clark, 1994; Smith \& Clark, 1993) in the beginning of their utterance.

There is evidence that fillers can perform a warning function to warn his or her listener about the delay in producing a word or phrase by uttering fillers; speakers answering general knowledge questions display accurate information about their mental search processes (Brennan \& Williams, 1995; Smith \& Clark, 1993); which are, they will pause longer and use more fillers before giving an answer which they lack confidence in (and is likely to be incorrect) than before they give an answer that they have a strong feeling about (and that is more likely to be correct). They even pause longer and use more fillers before a non-answer (e.g., I don't know), when actually they do know the answer but are just unable to recall it at the moment of speaking. Listeners can use this metacognitive display to judge how likely it is for the speaker to know the correct answer (Brennan \& Williams, 1995).
Intensifiers are adverbs that enhance adjectives and adverbs and come before the words they modify. In Graddy's (2006) study, the amount of intensifiers used by both male and female was less when compared to the amount of qualifiers used. Only minor differences in the use of intensifiers were evident when the male and female usage was compared. Female students used slightly more intensifiers than males. The word 'very' was used more by men in Fahy's (2002) study. However, in Graddy's (2006) study women used more of this word. Women also used the intensifier 'less' more than men.

\section{METHOD}

This study looks at the sociolinguistic theory of Lakoff $(1973,1975)$ who talks about speech style, differences of speech and gender differences in speech. Lakoff's model indicates that there are a number of characteristics to focus on when studying speech styles and Table 1 illustrates.

Table 1: Features and examples in speech styles

\begin{tabular}{|c|c|c|}
\hline No & Types & Examples \\
\hline 1 & Questions & $\begin{array}{l}\text { a. tag questions e.g. They didn't hit you did they? } \\
\text { b. WH-questions e.g. What's your name? }\end{array}$ \\
\hline 2 & Fillers & umm, uh, ah, mm \\
\hline 3 & Hedges & $\begin{array}{l}\text { a. phrase type e.g. I think/assume/guess, I mean } \\
\text { b. Adverbial e.g. maybe, probably, relatively, generally } \\
\text { c. Adverbial used with the negative } \\
\text { e.g. (not) really, (not) necessarily, (not) very } \\
\text { d. generalized adjunct } \\
\text { e.g. or something, or whatever, sort of, kind of }\end{array}$ \\
\hline 4 & Intensifiers & Sub-modification: so, very, etc. \\
\hline 5 & Affirmatives & Yeah, OK, All right, Oh, Well in utterance-initial position \\
\hline 6 & Adjective Types & Wonderful, darling, lovely \\
\hline
\end{tabular}

Source: Lakoff's study (as cited in Michael, A. S., Chone, L. S., Muthusamy, C., \& Veeravagu, J. (2010).

From the examples above, only two types of linguistic features which are fillers and intensifiers will be the focus of this study.

The participants were 10 male Nigerians and 10 male Chinese learners' sourced from a private tertiary education institution. The learners' were in their last semester of the English program offered by a public institution of higher education. All learners have gone through four semesters of English courses (see appendix A) offered. The four levels of English courses that they have gone through are Proficiency Skills in English, Academic English, English for Research Foundation and English for Integrated Skills. The average age of the learners is 23.2 years old for the learners form Nigeria. Majority came from the northern part of Nigeria. Eighty percent of the learners' first language is the Hausa language and the remaining 20 percent is the Kanuri and Yoruba language. 
As for the learners from China their average age is 21.8 years old; forty percent of them came from the center of mainland China which is the Sichuan province and another 10 percent came from the Henan province. Their first language is Mandarin and information was retrieved from the questionnaire (see appendix B). Another 40 percent of the learners came from the East and South of China which were Hebei, Fujian and Shandong province.

Table 2: Demographic factor of Nigerian and Chinese learners

\begin{tabular}{|c|c|c|c|}
\hline Nigerian & Background information & Chinese & Background information \\
\hline $\mathrm{N} 1$ & $\begin{array}{c}\text { Age: } 26 \\
\text { North Nigeria } \\
\end{array}$ & $\mathrm{C} 1$ & $\begin{array}{c}\text { Age: } 22 \\
\text { Hebei province } \\
\end{array}$ \\
\hline N2 & Age: 24 & $\mathrm{C} 2$ & $\begin{array}{c}\text { Age: } 21 \\
\text { Henan province }\end{array}$ \\
\hline N3 & $\begin{array}{c}\text { Age: } 24 \\
\text { West Nigeria } \\
\end{array}$ & C3 & $\begin{array}{c}\text { Age: } 21 \\
\text { Sichuan province } \\
\end{array}$ \\
\hline N4 & $\begin{array}{c}\text { Age: } 20 \\
\text { North Nigeria (Kano state) }\end{array}$ & $\mathrm{C} 4$ & $\begin{array}{c}\text { Age: } 21 \\
\text { Hebei province } \\
\end{array}$ \\
\hline N5 & $\begin{array}{c}\text { Age: } 23 \\
\text { North Nigeria } \\
\end{array}$ & C5 & $\begin{array}{c}\text { Age: } 22 \\
\text { Sichuan province } \\
\end{array}$ \\
\hline N6 & $\begin{array}{c}\text { Age: } 22 \\
\text { North Nigeria } \\
\end{array}$ & C6 & $\begin{array}{c}\text { Age: } 21 \\
\text { Sichuan province }\end{array}$ \\
\hline N7 & $\begin{array}{c}\text { Age: } 23 \\
\text { North Nigeria } \\
\text { (Adamawa state) }\end{array}$ & $\mathrm{C} 7$ & $\begin{array}{c}\text { Age: } 22 \\
\text { Fujian province }\end{array}$ \\
\hline N8 & $\begin{array}{c}\text { Age: } 19 \\
\text { North Nigeria } \\
\text { (Katsina state) }\end{array}$ & C8 & Age: 23 \\
\hline N9 & Age: 27 & C9 & $\begin{array}{c}\text { Age: } 23 \\
\text { Shandong province }\end{array}$ \\
\hline N10 & $\begin{array}{c}\text { Age: } 24 \\
\text { North Nigeria }\end{array}$ & C10 & $\begin{array}{c}\text { Age: } 22 \\
\text { Sichuan province }\end{array}$ \\
\hline
\end{tabular}

The research took the following sequence. The materials and instruments needed were prepared. Next, the researcher asked the principal of the Language Centre for permission to carry out the study on the students. After that, the researcher informed the subjects of her intention to carry out the study. Following that, consent forms (Appendix C) were distributed to the learners' by the researcher. The researcher explains what they would be required to do and that findings will be shared with them. They were also given a chance to clarify the nature of study. The questionnaires were then distributed to the learners. The questionnaire consists of 17 questions (see Appendix B). The purpose of the questionnaire was to find out the profile of the learners' background. Participants were given the opportunity to ask questions if they did not understand or if they were not clear on certain things. All questionnaires were then collected on the spot and processed accordingly.

Prior to the collection of data, an appointment was set with the learners to meet up on a weekday (2011) to conduct the recording session of their speech. All the 20 learners had their own individual time slot (see Appendix D).

1. They would enter the discussion room and have a seat.

2. They were also given some time (around one or two minutes) to prepare themselves (to get familiar with the surroundings and to get ready to begin their speech).

3 . When they are ready they would begin their speech on "My family" and their speech would be recorded by using a smartphone. The title "My Family" was chosen as it was something familiar to the learners. 
4. All speeches recorded were transcribed (see Appendix E) according to the utterances.

The study does not focus on volume, pitch and non-verbal cues because of the constraints of time, space and also because the researcher did not video tape the learners during data collection as the learners did not let her video tape them. This study is also constrained by the number of Nigerian and Chinese learners the researcher had access to. Hence, the researcher approached learners who are readily available to her.

\section{RESULTS AND DISCUSSION}

The data presented here were collected to answer two research questions. The research questions explored were:

i. What are the speech styles of Nigerian and Chinese EFL learners?

ii. How are the speech styles of the Nigerian learners different from the Chinese EFL learners in terms of: a) fillers and b) intensifiers?

Speech style of Nigerian learners

Coupland (2007) says that speech styles are often applied as a strategy to signal social differences which enable the speaker to construct his/her own identity so that they become accepted by the target community. However, the section below only focuses on the speech styles of learners' from Nigeria.

As stated earlier, fillers enable conversations to run smooth whenever speakers are trying to retrieve information for some reason. However, not all speakers use fillers (Juan, 2006). Studies by Clark (1994) and Smith \& Clark (1993) have validated that fillers help to buy time to think, of what is going to be said next. Examples are words such as 'um', 'ah', 'mm', 'er' and so on.

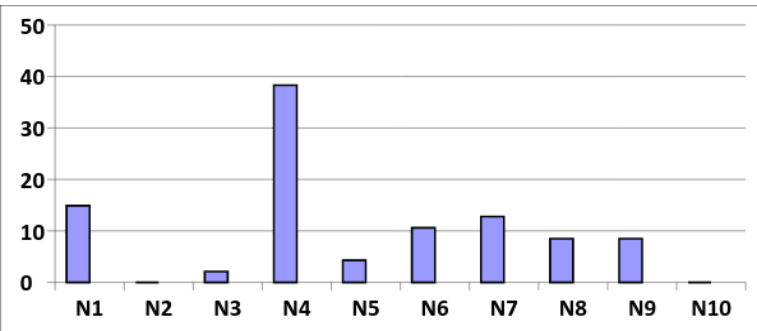

Figure 1. Percentage of fillers used by Nigerian learners

Findings showed that fillers were employed by the learners from Nigeria and China. Figure 1 shows the amount of fillers used by the Nigerian learners in their speech on "My Family". It is found that 80 percent of the learners had used fillers in their speech. The total amount of fillers used was 47.

Further analysis showed that the highest amount of fillers was used by $\mathrm{N} 4$ which is 38.3 percent followed by N1 which used 14.9 percent of fillers. N7 used 12.8 percent and N6 10.6 percent. N8 and 9 used four fillers each which is 8.5 percent. N5 used 4.3 percent of fillers. Learners N2 and N10 did not use any filler in their entire speech. This indicates that the extent of fillers used can vary between speeches and that it is not a 'rigid' characteristic of Nigerian speakers. To further illustrate, examples are provided in Table 3.

Table 3. Example of fillers used by Nigerian learners

\begin{tabular}{|c|c|}
\hline N1 & $\begin{array}{l}\text { : My name is } \text { err..Musa... (Utterance } 2) \\
\text { : I er..student from Nigeria (Utterance } 3 \text { ) } \\
\text { : I , I'm } \text { erm belong to the Hausa tribe.....(Utterance } 4)\end{array}$ \\
\hline N3 & : So, erm... my dad's name is......(Utterance 5) \\
\hline N4 & $\begin{array}{l}\text { : Er Assalamualaikum my name is } \boldsymbol{e r} \text { Hussaini...(Utterance 1) } \\
\text { : I come from } \boldsymbol{e r} \text { I come from Africa, Africa, Nigeria Nigeria from } \\
\text { Kano state (Utterance 2) } \\
\text { : } \boldsymbol{E r} \text { my tribe is Hausa and } \boldsymbol{e r} \text { I come from a family of nine (utterance 3) }\end{array}$ \\
\hline N5 & $\begin{array}{l}\text { : Then my siblings, among er.. my er.. our family I'm the only person } \\
\text { that went out abroad to study (Utterance 13) }\end{array}$ \\
\hline N6 & $\begin{array}{l}\text { : And } \text { er.. that time my father got married at the age of } 25 \text { years and } \\
\text { met my mother when he was } 24 \ldots(\text { Utterance } 4) \\
\text { : So } \text { er.. the my father, my mother's brother is the district head office } \\
\text { rural area so the well known and very popular person (Utterance 6) } \\
\text { : My father ...school ...attended this er.. degree programme (Utterance 20) }\end{array}$ \\
\hline
\end{tabular}




\begin{tabular}{ll}
\hline N7 & $:$ Er..I'm a Nigerian from the Northern part of Nigeria... (Utterance 2) \\
& $:$ Er.. my mom is currently in Nigeria working...(Utterance 3) \\
& $:$ Arr.. I live in a family of six which I'm the first family that...(Utterance 4) \\
\hline N8 & $:$ That's erm.. Katsina state (Utterance 4) \\
& $:$ Erm..I'm a Christian (Utterance 6) \\
& $:$ Erm..erm.. I have my dad's name is Thomas (Utterance 10) \\
& $:$ Good afternoon my lecturer and $\boldsymbol{e r . .}$ my name is...(Utterance 1) \\
& $:$ Er.. I come to Malaysia to er.. study B.I.T. (Utterance 2) \\
& $:$ Er.. I'm here almost three years in Malaysia (Utterance 3)
\end{tabular}

The table above shows that most of the time, the 'er' filler is being used by Nigerian learners in the beginning of a sentence. However, there are also instances when the use of fillers (er, erm) are found in the middle of a sentence. This finding supports what Froehlich (2010) says that is; in English, the most common filler sounds or words are er, uh and um. He also says that fillers can occur at different positions in a discourse which supports some examples given. By looking at the data transcribed (Appendix E), it can be said that the reason for the use of most fillers are because the learners pause before saying an important idea which helps signal that whatever said next is significant (DeVito, 2006). For example, N1: My name is err..Musa... (Utterance 2), I er.. student from Nigeria (Utterance 3). This shows that after introducing himself it is appropriate to talk about where he is from. Another reason why Nigerian learners' use fillers is because they would like to pause at transition points to signal that they are moving from one part of the speech to another which would help the listeners separate the main issues discussed (DeVito, 2006). For example, N7: Er.. my mom is currently in Nigeria working...(Utterance 3), Arr.. I live in a family of six which I'm the first family that...

(Utterance 4). This shows that the speaker is going to move from talking about his mom to talking about his siblings.

As discussed earlier, intensifiers are adverbs that enhance adjectives and adverbs and they come before the words they modify. In this case focus is given to words that heighten the intensity of other words such as 'very', 'so', 'most' and others.

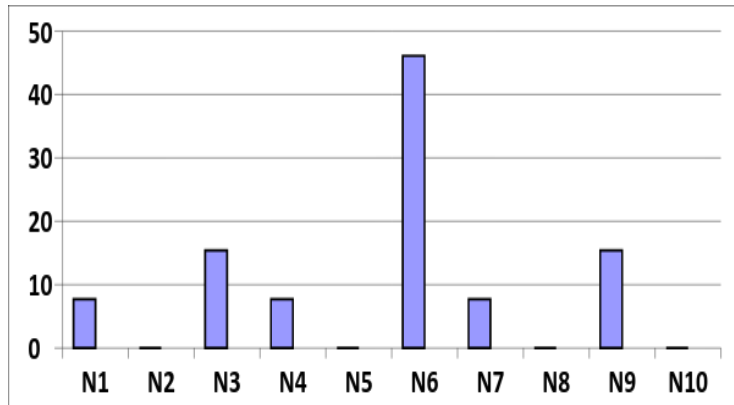

Figure 2. Percentage of intensifiers used by Nigerian learners

This study found that the use of intensifiers is not a common feature of the 10 Nigerian learners. Statistics are provided in Figure 2.

Looking at the graph above, it can be seen that 40 percent of the Nigerian learners do not use intensifiers in their speech. In this scenario, N6 used the most intensifiers in his speech. He used six intensifiers which is 46.1 percent of the total. He uses it to enhance the following words in his speech (Example: very popular person). The next common statistic came from N3 and N9 who both used equal amount of intensifiers which is 15.4 percent each followed by N1, N4 and N7 with 7.7 percent. Data indicate that speakers N2, N5, N8 and N10 did not use any intensifier at all. Examples are displayed in Table 4.

Table 4. Example of intensifiers used by Nigerian learners

\begin{tabular}{ll}
\hline $\mathbf{N 1}$ & $\begin{array}{l}\text { : So er actually Malaysia is very nice country to me but some people } \\
\text { still some people are complain about Malaysia (Utterance 11) }\end{array}$ \\
\hline N3 & $\begin{array}{l}\text { :..... but now its kinda very expensive 2.8, 2.9 (Utterance 16) } \\
\text { : But it's ok I'm almost done so nothing much to worry about } \\
\text { (Utterance 17) }\end{array}$ \\
\hline
\end{tabular}




\begin{tabular}{cl}
\hline N4 & : And this er.. biotech I'm not practicing anything but er.. my mother \\
& force me to just do it because she ar.. she accompany me here. \\
& (Utterance 11) \\
& : So er.. the my father, my mother's brother is the district head office \\
rural area so the well known and very popular person (Utterance 6) & : In that way ...in your relationship coz that make you familiar and make the \\
& relationship very strong to keep on going for the rest of your life (Utterance 19) \\
& : His major was commerce and then he went on and attended his \\
& masters and he worked at the bank for almost 20 years...(Utterance 21) \\
& : So and erm I came to Malaysia in 2008 and the reason is because \\
& Nigeria education is quite good but the problem is they represent a \\
& lot of strike (Utterance 23) \\
& : Er so that's pretty much about me (Utterance 29) \\
& : Thank you very much... (Utterance 30) \\
& : So and my country Nigeria is very famous country in Africa which \\
& is we call it the heart of Africa (Utterance 12) \\
& : So I'm just eager to go back and meet my children because they are \\
& missing me (laughs) (Utterance 7) \\
& : Thank you very much. (Utterance 11) \\
\hline
\end{tabular}

The table above shows that, the intensifier 'very' is being used frequently by Nigerians. The findings here support those findings by Fahy (2002) who says that the word 'very' is used more by men. However, this statement cannot be generalized as this study only looks at the speech styles of Nigerian males. In this study, no comparison can be mentioned for women Nigerian speeches. There are also instances of other intensifiers being used and they include 'almost', 'pretty' and 'quite'. Most of the intensifiers used by the Nigerian learners' were used before an adjective rather than before an adverb. For example, N1: "very nice country", N3: "very expensive", N6: "very popular person" and N7: "very famous country". By using intensifiers in their speech, it seems that the Nigerian learners are experiencing a passionate description about the topic spoken (Street \& Hopper, 1982).

\section{Speech styles of Chinese EFL learners}

As said before, this section will begin by focusing on the Chinese EFL learners' usage of fillers. Having discussed the Nigerian learners' speech style, the section below focuses on the learners' from China.

Fillers fill up a gap in an utterance (Cappelli, 2008) and may occur at different places in a discourse (DeVito, 2006).

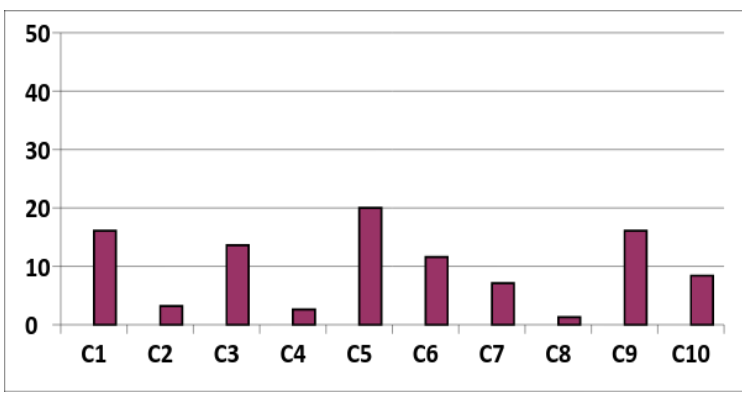

Figure 3. Percentage of fillers used by Chinese learners

Statistics are presented in Figure 3 and analysis shows that not all the Chinese learners used fillers in their speech. The total amount of fillers used was 155 which were more than the Nigerians (47 fillers). This shows that the Chinese are seen as unprepared and or nervous compared to the Nigerians as DeVito (2006) says that people who use fillers are seen as being hesitant, unprepared and unsure of themselves.

Figure 3 indicates that, the highest amount of fillers used was by $\mathrm{C} 5$ which is 20 percent, followed by $\mathrm{C} 1$ and $\mathrm{C} 9$ respectively with 16.1 percent each. Next is C3 with the use of 21 fillers which is 13.6 percent. C6 used 11.6 percent of fillers in his speech. C10 used 13 fillers which results to 8.4 percent. C7 used 7.1 percent of fillers followed by $\mathrm{C} 2$ which is 3.2 percent and C4, 2.6 percent. The lowest amount of fillers used was by $\mathrm{C} 8$ which is only 2 fillers with the amount of 1.3 
percent. The amount of fillers used may be due to the fact that Chinese learners' find it difficult to choose the right word (see Appendix B) hence, they find a need to delay their speech (Schachter, Christenfeld, Ravina \& Bilous, 1991). The section below illustrates some of the examples detected in their speech.

Table 5. Example of fillers used by Chinese learners

\begin{tabular}{|c|c|}
\hline C1 & $\begin{array}{l}\text { : Er..hello teacher (Utterance 1) } \\
: \text { Er..I come from China, Hebei province... (Utterance 3) } \\
\text { : Er..it's a small city my hometown(Utterance 4) }\end{array}$ \\
\hline $\mathrm{C} 2$ & $\begin{array}{l}\text { : Er.. I come from China (Utterance 2) } \\
\text { : Er..I was born in Henan province (Utterance 2) } \\
\text { : Erm..my mother, father, my brother and myself (Utterance 7) }\end{array}$ \\
\hline C3 & $\begin{array}{l}\text { : Erm my name Li Bo (Utterance 1) } \\
: \text { Er I live in Sichuan province Chengdu city (Utterance 4) } \\
\text { : Er..my family my family my family } \boldsymbol{e r . . ~ h a s ~ a ~ m y ~ f a t h e r , ~ m y ~ m o t h e r ~} \\
\text { and I (Utterance 5) }\end{array}$ \\
\hline $\mathrm{C4}$ & $\begin{array}{l}\text { : Er I'm now study Malaysia (Utterance 4) } \\
: \text { Er..my sister is a nurse (Utterance 9) } \\
: \text { Er.. er....(Utterance 10) }\end{array}$ \\
\hline C5 & $\begin{array}{l}\text { Erm my name is YangYang. (Utterance 2) } \\
: \boldsymbol{M m} . . \text { there are three people in my family my father, my mother and I (Utterance 4) } \\
: \text { Er my } \boldsymbol{e r} \text { I come to here I come to here in Malaysia study for } \\
\text { business finance because of is I no want to go here but in China } \\
\text { some people say that at at at this college is good so good } \boldsymbol{e r} \text { have } \\
\text { anything but anything have so I with my friend join join join } \boldsymbol{e r} \\
\text { university such as .....(Utterance 5) }\end{array}$ \\
\hline C6 & $\begin{array}{l}\text { : } \boldsymbol{E r} \boldsymbol{m m} \text { my name is Xu Ji Hong (Utterance 1) } \\
\text { : Er I'm from Tze Chuan province China (Utterance 4) } \\
\text { : So I have four person in my family } \boldsymbol{e r} \text { my father, mother, brother } \\
\text { and I (Utterance 7) } \\
: \text { Er.. (mumbling).. (Utterance 8) }\end{array}$ \\
\hline C7 & $\begin{array}{l}\text { : Ya take } \text { er music and performing (Utterance 7) } \\
: \text { I er now I want to talk about my family (Utterance 10) } \\
: \text { They } \boldsymbol{e r} \text { in college at China (Utterance 13) }\end{array}$ \\
\hline C8 & $\begin{array}{l}\text { : Er..my mother also (Utterance 5) } \\
: \text { Mm..so I only one child (Utterance 6) }\end{array}$ \\
\hline C9 & $\begin{array}{l}: \text { Er now I am } 23 \text { years old (Utterance 2) } \\
: \boldsymbol{E} \boldsymbol{r} \text { my hometown name is } \boldsymbol{e r} . . . .(\text { Utterance } 4) \\
: \boldsymbol{E r} \text { there are } 11000 \text { people in my hometown } \boldsymbol{e r} \text { but } \boldsymbol{e r} \text { there } \boldsymbol{a r} \text { are } 8 \\
\boldsymbol{e r} 8000 \text { people have } \boldsymbol{e r} \text { same family name (Utterance 5) }\end{array}$ \\
\hline C10 & $\begin{array}{l}\text { Er the Sichuan province in west in the China and this is beautiful } \\
\text { city called Chengdu because the city } \boldsymbol{e r} \text { people call the city } \boldsymbol{e r} \\
\text { abandoned city (Utterance } 3 \text { ) } \\
\text { : So it } \boldsymbol{e r} \text { have a } \boldsymbol{e r} \text { food have a special place and the people is very } \\
\text { hot and } \boldsymbol{e r} \text { kind (Utterance } 4 \text { ) } \\
\text { : So my family } \boldsymbol{e r} \text { three people my mom and dad (Utterance 6) }\end{array}$ \\
\hline
\end{tabular}

The examples above show that the filler that is most used by the Chinese EFL learners is the 'er' filler and this finding supports what DeVito (2006) says about the common English fillers being 'er', 'uh' and 'um' respectively. As can be seen, the fillers used by the Chinese learners' not only occur at the beginning of the utterance but also at different positions in the utterance such as in the middle of the utterance (DeVito, 2006). The position where most of the fillers occur is at the beginning of the sentence and this finding has been verified by Boomer (1965) and Shriberg (1996) who both say that fillers are more likely to occur in this position as this is where speakers are planning of what to say.

The focus of this study also looks at words that heighten the intensity of other words such as 'very', 'so', 'most' and others. Therefore, intensifiers which are adverbs that enhance adjectives and adverbs that come before the word they modify will be discussed further. 


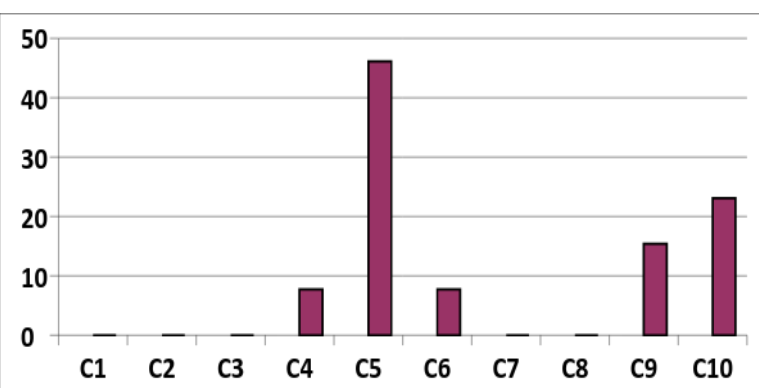

Figure 4. Percentage of intensifiers used by Chinese learners

Figure 4, indicates the amount of intensifiers used by each Chinese learner in their speech. The learner who used the most number of intensifiers in his speech is $\mathrm{C} 5$. He used six intensifiers in his speech which amounts to 46.1 percent. C10 used 23.1 percent of intensifiers and C9 15.4 percent. C4 and C6 used only one intensifier each. Five learners, which are C1, C2, C3, C7 and C8, did not use any intensifier in their speech. Even though 50 percent of learners did not use intensifiers in their speech, it cannot be generalized that there is no significant difference between men and women in terms of the usage of intensifiers in their speech (Nemati \& Bayer, 2007). Further studies should be carried out to find out if some men use intensifiers because of certain things they wish to portray or if certain men just do not use any intensifiers at all regardless of what they wish to portray. Examples of the intensifiers used are illustrated in Table 6.

Table 6. Example of intensifiers used by Chinese learners

\begin{tabular}{|c|c|}
\hline $\mathrm{C4}$ & $\begin{array}{l}\text { : Malay...why I come come to Malaysia is Malaysia is Malaysia is } \\
\text { very beautiful (Utterance 5) }\end{array}$ \\
\hline C5 & $\begin{array}{l}\text { : But my but my housemate he is very good (Utterance 8) } \\
\text { : So I'm more confident in this college (Utterance 14) } \\
\text { : First one is football, second one is snooker er because of here is so } \\
\text { boring so I I cannot talk about this with my friends er not like } \\
\text { people in China (Utterance 17) } \\
\text { : You are so good (Utterance 24) } \\
\text { : We are very happy and er so we always make aarrr game } \\
\text { (Utterance 26) } \\
\text { : So it is interesting and you are the most beautiful teacher er in my } \\
\text { life. (Utterance 27) }\end{array}$ \\
\hline C6 & $\begin{array}{l}\text { : Er er he is very busy and er sometimes he cannot sleep even for } \\
\text { three hours one day when he is in a busy day. (Utterance 15) }\end{array}$ \\
\hline C9 & $\begin{array}{l}\text { Erm erm I I I study in Malaysia because erm Malaysia is very near } \\
\text { er to my hometown er and I can I can learn er..more very little } \\
\text { money (Utterance 11) }\end{array}$ \\
\hline C10 & $\begin{array}{l}\text { : So it er have a er food have a special place and the people is very } \\
\text { hot and er kind (Utterance } 4 \text { ) } \\
\text { : So we live together and erm they are very good (Utterance 8) } \\
\text { : Er so why I am studying music coz I think er the world have a } \\
\text { many different languages so much but music is the one language } \\
\text { for the world.(Utterance 10) }\end{array}$ \\
\hline
\end{tabular}

By looking at Table 6, it can be concluded that males do use the intensifier 'very' most of the time (Fahy, 2002) and both Nigerian and Chinese EFL learners' use the word 'very' frequently. It can also be seen that the word which the intensifiers modify are adjectives. Examples can be seen in C4's speech: "very beautiful", C5: "very happy", C6: "very busy", C 10: "very hot" and others. The Chinese learners' use a variety of other intensifiers in their speech compared to the Nigerians. The Chinese use words such as more, so, and most. Examples are: C5: "more confident", "most beautiful" and C10: "so much".

\section{Differences in speech style of Nigerian and Chinese EFL learners}

This section states some information which can help to state the differences of the two groups of learners.

In terms of fillers found it was clear that the Chinese learners' use it more 
frequently as compared to the Nigerians. A further description will be given below.

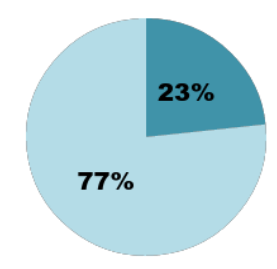
Nigerian Learners
Chinese Learners

Figure 5. Percentage of fillers used by Nigerian $\&$ Chinese learners

As stated in the pie chart above, Chinese learners use fillers at a much higher frequency in their speech which is 77 percent as compared to Nigerian learners which is only 23 percent.

Filled pauses are hesitant sounds made to indicate uncertainty or simply to maintain control of the conversation by thinking of what to say next (Cappelli, 2008). Since the Nigerian learners used less filler in their speech, it shows that they are more proficient in the language as they do not hesitate when speaking. They do not need to buy some time thinking of what to say before they start speaking. This also shows that Nigerian learners are more comfortable as compared to Chinese in using the English language. As DeVito (2006) says, pauses are seen as ineffective as it weakens your message. If used, the speaker would be perceived as hesitant, unprepared and unsure of yourself. Nigerians tend to appear more confident compared to the Chinese probably because apart from their own mother tongue they tend to use English as a language for them to communicate daily with college friends and also to help them buy food especially in Malaysia, as the questionnaire information has shown. All 10 of them agreed that they use the English language to complete assignments, to Facebook, to write letters and emails (see Appendix B). Other than that, they also agreed that English is used when travelling and also to make friends (see Appendix B). Apart from that they also have more experience using the language as many of them have been to English medium schools for at least 12 years (see Appendix B). In that regard, they could be considered to be proficient in the language. As the Chinese learners use the powerless speech style, they are seen as less confident and unsure of themselves. This supports what Parton, Siltanen, Hosman \& Langenderfer (2002) say. What is interesting is that even though the Nigerian learners are considered to be proficient, some of them faced some difficulties when speaking in English. Two found it difficult to construct sentences whereas one of them found it difficult to pronounce certain words and another sometimes find it difficult to find the right words when he speaks (see Appendix B). The difficulties faced by the learners support what Bardovi-Harlig \& Hartford, (1990), Eisenstein \& Badman, (1986), Olshtain \& Cohen, (1983) have said about L2 learners. That is, learners' may also find it hard to send and receive messages using their L2 regardless of their proficiency level, depending on context, speakers and topic of conversation (Yuan, Liberman \& Cieri, 2006). In this regard their fluency was possibly affected by the task because they were asked to give a speech which was recorded and they were also the only one present in the room apart from the researcher.

As for the Chinese learners, they are found to be less confident which means that they appeared not prepared and they hesitate a lot before speaking probably because they used their own mother tongue most of the time in their daily lives as information in the questionnaire indicates. This finding supports previous research of Brennan \& Williams (1995); Smith \& Clark (1993) where they say that people tend to pause longer and use more filler before giving an answer, suggesting a lack of confidence (Brennan \& Williams, 1995; Smith \& Clark, 1993). Speakers who used their first language frequently to communicate with others such as their parents, relatives, friends and many more tend to fall under this category where they are seen as less confident. It is clear that the Chinese learners' use English as a final choice, i.e. when it is really necessary, for example, to complete assignments and write reports related to studies (see Appendix B). Apart from that information from the questionnaire also illustrates that they have 
less experience using the language since many of them have only been to English medium schools for 6 years as compared to the Nigerians (see Appendix B). From the questionnaire, all ten learners also indicated that they have difficulties when speaking in English (see Appendix B). This information explains why the learners face difficulty in the pronunciation of words (see Appendix B). This may be due to the lack of practice and exposure to the language (see Appendix B). They also do not have adequate vocabulary for conversing which makes it difficult for them to deliberate using the language. Nevertheless, the information gained does not support what Schachter, Christenfeld, Ravina \& Bilous (1991); Schachter, Rauscher, Christenfeld, \& Crone, (1994) say which is that speakers who use more filler in their speech tend to have a larger range of vocabulary to choose from. This study had shown that Chinese EFL learners may know what they would like to convey but they were hampered by the lack of vocabulary to say what they want and need to say. This gap leaves them struggling during a conversation to convey the message. Ultimately, Chinese learners' would use any word they know just to convey enough information as the study illustrates. This information supports what DeVito (2006) says: that if the words you use are able to convey your message it means that it was a successful speech. The Chinese learners used more filler to expand on their speech. Fillers helped them to think of what they would like to say as well as how to construct the sentence before actually saying it (Cappelli, 2008) but in this study, the Chinese EFL learners were eventually defeated by their lack of practice in using the English language.

In a nutshell, it can be said that learners tend to use fillers when they find it difficult to get the right words and when this occurs, there was a greater need to delay their speech (Schachter, Christenfeld, Ravina \& Bilous, 1991) and ultimately they filled up their utterances with pauses and fillers.

Street \& Hopper (1982) say that language intensity can be another way of evaluating speech styles. The language used will get more intense as the speaker gets more emotional when he/she is speaking.

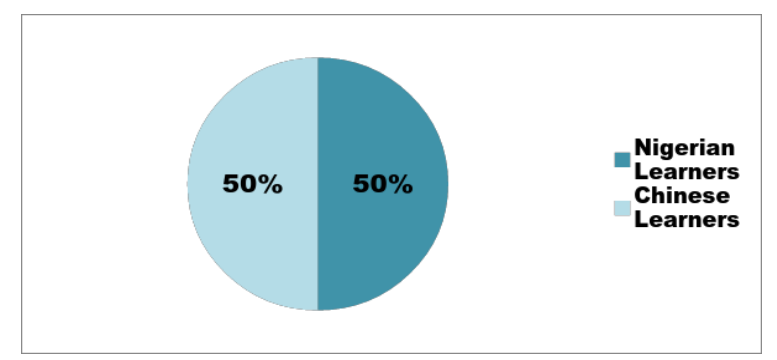

Figure 6. Percentage of intensifiers used by Nigerian \& Chinese Learners

Figure 6 demonstrates that the Nigerian learners used the same amount of intensifiers as the Chinese learners.

No deduction could be made of this finding since four learners from Nigeria and five learners from China did not use any intensifier. Even though many linguists mention that men tend not to add decorations to their speech the way women do (Murphy, 2006), there are instances in this study which differed. For instance, many intensifiers were used in these EFL learners' speeches. Learners tend to use intensifiers to make something sound more or less exciting and these adverbs can portray the listener's feelings about the concept (Robert, 2011). It also seems that learners from both Nigeria and China use intensifiers most frequently in front of adjectives rather than adverbs. Only a few instances of intensifiers were used in front of adverbs. For example, $\mathbf{N 9}$ where he said "Thank you very much", C9 “...very little money" and C10 "....so much but music..."

The results of the four Nigerian and five Chinese learners (N2, N5, N8, N10, C1, C2, C3, $\mathrm{C} 7$ and C8) who did not use intensifiers support the findings or opinion of Larner, (2009) which states that intensifiers are characteristic of feminine language and men tend to make use of fewer intensifiers because men detract from the primary content of a statement and make it less persuasive or realistic by exaggerating and adding emotional content to it. The researcher found that $\mathbf{N} \mathbf{6}$ used a rather strong expressive in his speech when he said "....this kind of mentality you have back in......" It sounded like the speaker was very angry or upset about it. This supports what Kramer (1974) says that 
males use stronger expressive when they are angry or exasperated. Another study by Kuha (2005) states that there is no clear pattern which says that women use more intensifiers in their speech. She suggests that both men and women use intensifiers at roughly similar frequency and this need to be further verified for Nigerian and Chinese learners who are females.

\section{CONCLUSION}

Chinese learners use more fillers as they are unsure about what to say (Smith, Siltanen \& Hosman, 1998). It also shows that they hesitate a lot before saying something (DeVito, 2006). This is because the learners use very minimum English in their daily lives and only if they are required to (Appendix B). And because they do not use the language often, they do not have sufficient vocabulary to appear confident when giving their speech.

The Nigerian learners are more confident compared to the Chinese learners hence the use of less fillers. Nigerian learners are exposed to the language way earlier in their life compared to the Chinese (Appendix B). Hence, they are more proficient in the language. They do not hesitate much when speaking. This is because they are quite comfortable when using the English language as they often communicate with friends in English as well as in their daily lives (Appendix B).

As for the use of intensifiers, both the Nigerian and Chinese learners' use the same amount of intensifiers in their speech. They use intensifiers as they want to show the degree of intensity of a certain word. It cannot be said that all males use intensifiers in their speech as 40 percent of the Nigerian learners' and 50 percent of the Chinese learners' did not use intensifiers in their speech.

Some recommendations are offered as guidelines for consideration and possible application by future researchers who would like to carry out a similar research of speech styles.

1. Instrument to record speech It could be seen that some of the learners were uncomfortable as there was a mobile phone in sight which is recording their speech. May be the device should be hidden so that the learners will actually feel like it is their normal environment.

2. Environment

When the learners were called into the discussion room one by one to give their speech there was rather a lot of pressure on them. This might have an effect on their performance. The researcher should just record their speech during their class presentation in front of their friends where they might feel more secure as there is support from their peers.

3. Length of Speech Before the recording session takes place the researcher should give the learners a minimum time frame for their speech. This is to make sure that the length of speech is rather standardized.

\section{ACKNOWLEDGEMENTS}

Many people have helped in so many ways to complete this research. It would not have been possible without their support and help. Therefore, I would like to express many thanks to all but in particular Associate Prof. Dr. Kuang Ching Hei for her patience and her valuable and constructive suggestions during the planning and development of this project. I would also like the opportunity to thank my family and friends for always keeping my progress on schedule and for always being there to support and encourage me throughout the years.

\section{References}

Ali J. M. (1995). Indirectness in Malay Diplomacy with Particular Reference to Business Dealings and Labour Relations. Jurnal Bahasa Moden, 9, 112124.

Ali J. M. (2000). Verbal communication: A study of Malaysian speakers. Kuala Lumpur: University of Malaya Press.

Al-Issa, A. (2003). Sociocultural transfer in L2 speech behaviors: Evidence and motivating factors. International Journal of Intercultural Relations, 27, 581-601.

Bardovi-Harlig, K., \& Hardford, B. S. (1990). Congruence in native and nonnative conversations: status balance in the academic advising session. Language Learning, 40, 467-501.

Boomer, D. S. (1965). Hesitation and grammatical encoding. Language and Speech, 8, 148-158. 
Bradac, J. J. \& Mulac, A. (1984). A molecular view of powerful and powerless speech styles: Attributional consequences of specific language features and communicator intentions. Communication Monographs, 51, 307-319.

Bradac, J., Mulac, A., \& Thompson, S. (1995). Men's and women's use of intensifiers and hedges in problem-solving interaction: Molar and molecular analyses. Research on Language and Social Interaction, 28, 93-116.

Brennan, S. E., \& Williams, M. (1995). The feeling of another's knowing: Prosody and filled pauses as cues to listeners about the metacognitive states of speakers. Journal of Memory and Language, 34, 383-398.

Cappelli, G. (2008). Fillers (Discourse Markers \& Co.) and Backchannels. Retrieved October 17, 2012, from http://www.gloriacappelli.it/wpcontent/uploads/2009/05/lesson04-05.pdf.

Clark, H. H. (1994). Managing problems in speaking. Speech Communication, 15, 243-250.

Clark, H. H., \& Brennan, S. E. (1991). Grounding in communication. In L. B. Resnick, J. Levine, \& S. D. Teasley (Eds.), Perspectives on socially shared cognition (pp.127-149). Washington, DC: APA. Reprinted in R. M. Baecker (Ed.), Groupware and computer-supported cooperative work: Assisting human-human collaboration (pp. 222- 233). San Mateo, CA: Morgan Kaufman Publishers, Inc.

Coupland, N. (2007). Style: Language variation and identity. Cambridge: Cambridge University Press.

Crystal, D. (1971). Stylistics, fluency, and language teaching. In Interdisciplinary approaches to language (London: CILT). Occasional Paper, 6, 34-53. Part reprinted in Kachru \& Atahlke.

David, M.K. \& Hei, K. C. (1999). Interethnic Variations in the Use of Directives in Malaysia in The Hong Kong Linguist. Journal of the Institute of Linguists, (19-20), 36-44.

DeVito, J. A. (2006). Human communication: The basic course. International Edition (10th ed.). USA: Pearson.

Eisenstein, M., \& Bodman, J. (1986). I very appreciate: Expressions of gratitude by native and nonnative speakers of American English. Applied Linguistics, 7, 167-185.

Erickson, B., Lind, E. A., Johnson, B. C., \& O’Barr, W. M. (1978). Speech style and impression formation in a court setting: The effects of powerful and powerless speech. Journal of Experimental Social Psychology, 14, 266-279.

Fahy, P. J. (2002). Use of linguistic qualifiers and intensifiers in a computer conference. American Journal of Distance Education, 16(1), 5-22.

Fragale, A. R. (2006). The power of powerless speech: The effects of speech style and task interdependence on status conferral. Organizational Behavior and Human Decision Processes, 101, 243-261.

Froehlich, H. (2010, July 5). Um, filler words and, like, how they function in... uh language, you know? Boston linguistics / Examiner.com.
Retrieved January 12, 2012, from http://www.examiner.com/article/um-fillerwords-and-like-how-they-function-uh-languageyou-know.

Giles, H. \& Smith, P. M. (1979). Accommodation theory: Optimal levels of convergence. In H. Giles and R. St. Clair (Eds.), Language and Social Psychology, pp. 45-65. Oxford: Blackwell.

Giles, H. \& Street, R. (1985). Communicator characteristics and behavior. In M. L. Knapp and G. R. Miller (Eds.), Handbook of Interpersonal Communication, pp. 205-61. Beverly Hills, CA: Sage.

Giles, H. (1973). Accent mobility: A model and some data. Anthropological Linguistics, 15, 87-105.

Giles, H., Mulac, A., Bradac, J. J. \& Johnson, P. (1987). Speech accommodation theory: The next decade and beyond. In M. McLaughlin (Ed.), Communication Yearbook 10, pp. 13-48. Newbury Park, CA: Sage.

Graddy, D. B. (2006). Gender salience and the use of linguistic qualifiers and intensifiers in online course discussions. American Journal of Distance Education, 20(4), 211-229.

Hei, K. C. (2002). The implications of lah, ah and hah as used by some speakers in Malaysia. Jurnal Bahasa Moden Keluaran 14, September 2002 pp. 133-154.

Hosman, L. A. \& Siltanen, S. A. (1994). The attribution and evaluative consequences of powerful and powerless speech styles: An examination of the "control over others" and "control of self" explanations. Language \& Communication, 14, 287-298.

Hosman, L. A. (1989). The evaluative consequences of hedges, hesitations, and intensifiers: Powerful and powerless speech styles. Human Communication Research, 15, 383-406.

Juan, S. (2006). Why do we say 'um', 'er', or 'ah' when we hesitate in speaking? Retrieved May 26, 2012 from The Register. Website: http://www.theregister.co.uk/2006/05/06/the _odd_body_language_fillers/

Kramer, C. (1974). Folklinguistics. Psychology Today, pp. 82-85.

Kuha, M. (2005). Investigating the Spread of "so" as an Intensifier: Social and Structural Factors. CUREJ - College Undergraduate Research Electronic Journal, 48, 217-227.

Lakoff, R. T. (1973). Language and woman's place. Language in Society, 2(1), 45-80.

Lakoff, R. T. (1975). Language and women's place. New York: Harper \& Row.

Larner, L. R. (2009). The role of feminine rhetoric in male presidential discourse: Achieving speech purpose. CUREJ - College Undergraduate Research Electronic Journal.

McMullen, L. M. \& Pasloski, D. D. (1992). Effects of communication apprehension, familiarity of partner, and topic on selected "woman's language" features. Journal of Psycholinguistic Research, 21, 17-30. 
Michael, A. S., Chone, L. S., Muthusamy, C. \& Veeravagu, J. (2010). Gendered-linked differences in speech styles: Analysing linguistic and gender in the Malaysian context. Cross-cultural Communication, 6(1), 18-28.

Murphy, P. (2006). Improve communication skills with the opposite sex. Retrieved May 26, 2012 from Earthling Communication. Website: http://www.earthlingcommunication.com/a/att raction/improve-communication-skills-malesfemales.php.

Nemati, A. \& Bayer, M. J. (2007). Gender differences in the use of linguistic forms in the speech of men and women: A comparative study of Persian and English. Glossa, 1 (3), 185-201.

Olshtain, E. \& Cohen, A. D. (1983). Apology: a speech act set. In N. Wolfson, \& E. Judd (Eds.), Sociolinguistics and language acquisition (pp. 18-35). Rowley, MA: Newbury.

Omar, A. H. (1992). The linguistic scenery in Malaysia. Kuala Lumpur: Dewan Bahasa dan Pustaka.

Omar, A. H. (1995). Rules of speaking: Indirectness as a rule of speaking among the Malays. Kuala Lumpur: Pelanduk Publications.

Parton, S. R., Siltanen, S. A., Hosman, L. A. \& Langenderfer, J. (2002). Employment interview outcomes and speech style effects. Journal of Language and Social Psychology, 21, 144-161.

Reiman, T. (2006). Gender differences. Retrieved June 12, 2012, from http://www.bodylanguageuniversity.com/publi c/213.cfm

Robert, C. (2011). Rational \& emotional strategies for persuasive language. Retrieved May 26, 2012 from eHow Contributor. Website: http://www.ehow.com/info_10007976_rational -emotional-strategies-persuasive-language.html.

Schachter, S., Christenfeld, N., Ravina, B. \& Bilous, F. (1991). Speech disfluency and the structure of knowledge. Journal of Personality and Social Psychology, 60, 362-367.

Schacter, S., Rauscher, F., Christenfeld, N., \& Crone, K. T. (1994). The vocabularies of academia. Psychological Science, 5, 37-41.

Shriberg, E. (1996). Disfluencies in switchboard. proceedings, international conference on spoken language processing (ICSLP' 96), Vol. Addendum, 11-14. Philadelphia. PA, 3-6 October.

Smith, V. \& Clark, H. H. (1993). On the course of answering questions. Journal of Memory and Language, 32, 25-38.

Smith, V., Siltanen, S. A. \& Hosman, L. A. (1998). The effects of powerful and powerless speech styles and speaker expertise on impression formation and attitude change. Communication Research Reports, 15, 27-35.

Street, R. L. \& Giles, H. (1982). Speech accommodation theory: A social cognitive approach to language and speech behavior. In M. Roloff and C. R. Berger (Eds.), Social Cognition and Communication, pp. 193-226. Beverly Hills, CA: Sage.

Street, R. L., Jr. \& Hopper, R. (1982). A model of speech style evaluation. In E. B. Ryan \& H. Giles (Eds.) Attitudes Towards Language Variation, 175-188. London: Edward Arnold.

Tannen, D. (1990). You just don't understand: Women and men in conversation. New York: William Morrow.

Wide, S. (20 April 2010). Second-language and the accommodation theory. Retrieved from http://ezinearticles.com/?Second-Languageand-the-Accommodation-Theory\&id=4146267

Yuan, J., Liberman, M. \& Cieri, C. (2006). Towards an integrated understanding of speaking rate in conversation. Proceedings of Interspeech 2006, pp. 541-544. 